Article

\title{
Analysis of Socioeconomic and Behavioral Factors Influencing Participation in Community-Based Recycling Program: A Case of Peri-Urban Town in Thailand
}

\author{
Amornchai Challcharoenwattana and Chanathip Pharino * \\ Department of Environmental Engineering, Faculty of Engineering, Chulalongkorn University, \\ Bangkok 10330, Thailand; amornchai.c@chula.ac.th \\ * Correspondence: chanathip.p@chula.ac.th
}

Received: 6 October 2018; Accepted: 26 November 2018; Published: 29 November 2018

check for updates

\begin{abstract}
This study analyzed the factors influencing a community-based waste recycling program to achieve a recycling rate 5-11 times/members higher than average community-based recycling programs in Thailand. This study identified key factors and insights from waste bank members to provide recommendations for improving the performance of other community-based programs. A face-to-face survey was conducted in Phang Khon Municipality (PKM), Thailand, where the waste bank is situated. A total of 386 questionnaires were analyzed by descriptive statistics and multinomial logistic regression analysis. The investigation tested how selected variables, such as socioeconomic factors, attitude toward sound waste management practices, types of waste separation, and additional willingness to pay for improving the waste management system, have an influence on different groups of recyclers and impact recycling performance. The findings revealed that members of the waste bank have different socioeconomic and pro-recycling characteristics, i.e., attitude toward proper waste management practices, recycling practice, and additional willingness to pay for improving the waste management system, compared to respondents who recycle through direct waste selling, and who do not recycle. Based on key factor findings in this study, policy recommendation for waste management entities are provided.
\end{abstract}

Keywords: socioeconomics factor; community-based recycling; curbside pickup; MSW

\section{Introduction}

\subsection{Solid Waste Management in Thailand}

Like many developing countries, Thailand has followed the global trend of rising economic output and the increase of in municipal solid waste (MSW) generation, both in terms of aggregate and per capita [1-3]. From Table 1, Thailand's MSW generation rates rose along with urbanization and MSW composition such as food, paper, and plastic-which were all found at similar levels across different urbanization levels. However, the expansion of new landfills or other MSW management methods did not increase accordingly. The condition of MSW disposal sites in Thailand is also in need of significant improvement to ensure the soundness of environmental and social conditions, as only $11.74 \%$ of MSW disposal sites met the nation's disposal site standards, serving a mere $36 \%$ of generated MSW in Thailand [4]. 
Table 1. Municipal solid waste (MSW) generation rate and characteristics from settlements with different levels of urbanization $[1,5]$.

\begin{tabular}{|c|c|c|c|c|c|c|c|c|c|c|}
\hline & $\begin{array}{c}\text { MSW } \\
\text { Generation Rate } \\
\text { (kg/Capita.Day) }\end{array}$ & $\begin{array}{c}\text { Food } \\
\text { Waste (\%) }\end{array}$ & $\begin{array}{l}\text { Paper } \\
(\%)\end{array}$ & $\begin{array}{l}\text { Plastic } \\
(\%)\end{array}$ & $\begin{array}{l}\text { Glass } \\
(\%)\end{array}$ & $\begin{array}{c}\text { Metal } \\
(\%)\end{array}$ & $\begin{array}{l}\text { Wood } \\
(\%)\end{array}$ & $\begin{array}{c}\text { Rubber/Leather } \\
(\%)\end{array}$ & $\begin{array}{l}\text { Textile } \\
(\%)\end{array}$ & $\begin{array}{c}\text { Miscellaneous } \\
(\%)\end{array}$ \\
\hline $\begin{array}{c}\text { Nakorn type } \\
\text { (Population }>50,000)\end{array}$ & 1.89 & 65.2 & 7.2 & 17.0 & 3.5 & 1.8 & 0.5 & 0.5 & 1.4 & 3.2 \\
\hline $\begin{array}{l}\text { Muang type }(10,000< \\
\text { Population }<50,000)\end{array}$ & 1.15 & 64.1 & 7.7 & 17.5 & 2.7 & 1.8 & 0.9 & 0.5 & 1.4 & 3.6 \\
\hline $\begin{array}{l}\text { Thumbon type } \\
\text { (Population < 5000) }\end{array}$ & 1.02 & 64.4 & 7.6 & 17.3 & 3.3 & 1.9 & 0.9 & 0.9 & 1.2 & 2.7 \\
\hline
\end{tabular}

In Thailand, town management authorities have relied on landfilling as their primary MSW management (MSWM) choice due to many short-term benefits such as low upfront investment [6], short lead time for commissioning a landfill, simple permitting procedure operation, and currently no legal requirements to conduct an environmental impact assessment [7]. However, those short-term benefits are often overriden by the long-term social costs. When the externalized costs incurred by society, e.g., cost of social and environmental damages, are considered, the aggregated societal cost can increase substantially $[8,9]$. The externalized costs from landfilling can account for an additional $7 \%$ to $32 \%$ of direct costs [10], and are likely to increase depending on the landfill's size [11]. In the long run, the benefits of the low upfront costs for landfilling are removed by long-term adverse environmental and social costs.

In addition to social costs, landfill incidents in Thailand occur frequently. For example, between 2013 and 2016, 36 landfill fire events occurred in Thailand [4,12,13]. Various landfills in Thailand were also inundated. The major flooding in 2011 demonstrated the vulnerability of landfill management in Thailand, as many landfills in the central plain were inundated [12]. Recent regional flood events in Thailand have also frequently affected landfill sites, e.g., the southern flood of 2016-2017 and the northeastern flood of 2017. It can be expected that pollution problems still occur since Thailand does not impose strict waste separation on hazardous, recyclable, and e-waste, negative health and environmental impacts. This can cause severe damage in surrounding communities.

Although environmental impact studies on Thailand-specific landfill disasters is limited, literature reviews on landfill disaster events from similar events revealed evidence of environmental damages, including surface and ground water contamination [14], air pollution [15,16], soil pollution [17,18], as well as greenhouse gases that contribute to climate change [19].

\subsection{Informal and Community-Based MSW Management}

Without mandatory waste separation and recycling in the formal waste management, recycling activities are generally done during collection or at the landfill site. In many developing countries, informal waste workers perform multiple roles in facilitating MSW collection through hauling wastes from generation points, sorting and separating recyclables before discarding rejected wastes to its disposal site. There are higher diversion rates of recyclables compared to that of urban settlements which do not allow informal recycling [20].

Waste scavenging and itinerant recyclable buying are often tolerated in low- and middle-income countries as those informal waste recycling are self-funded, and the cost of running those operations are not booked in the government's budget, unlike official curbside or drop-off recycling that is run by the local government [21]. However, the quality of recyclables is often poor due to contamination by wet wastes, resulting in degradation of economic value and they may eventually be deemed not suitable for recycling [20]. In addition, significant loss of opportunity for material recovery are depicted as the efficiency of ragpickers on removing recyclables was reported at $4 \%$ to $12 \%$ of MSW arrived at the landfill [22-24] while non-organic composition in MSW in lower-middle income countries were within $36 \%$ to $46 \%$ of MSW composition [3]. Additionally, even modern material recovery facility (MRF) may not outdo traditional scavenging activities if at-source separation is not present [25].

Alternatively, community-based management (CBM) activities (a collaboration of stakeholders organized on a voluntary basis for improvement of product or service) have been recognized widely as an 
alternative means to lessen the stress on MSWM, as CBM supports the waste hierarchy by promoting reuse and recycling of MSW through composting [26], recyclable separation and recycling [24,27]. In addition, recyclables accepted into CBM are pre-sorted by members, resulting in better quality of recyclables. Studies on CBM on waste management efficiency revealed that community-based MSWM (Municipal Solid Waste Management) in six developing cities were more cost-effective compared to the formal MSWM system [20]. In Thailand, CBM is mainly organized as a part of school or local activities under the banner "Waste Bank." Nevertheless, effectiveness of those waste banks varies significantly as seen in Table 2. Due to its voluntary nature, the success of the waste bank has varied from highly successful [27] to project cancellation due to low participation in the long-term scheme of things $[27,28]$.

Table 2. Performance of community-based non-organic waste recycling operations (Adopted from Challcharoenwattana and Pharino [24]).

\begin{tabular}{cccc}
\hline Activity & Incentive & Reutilization Metric \\
\hline & Waste Bank Operations & \\
\hline Rayong municipality, Thailand [29] & Community recognition and cash return & $17.33 \mathrm{~kg} / \mathrm{member}$ \\
Yala municipality, Thailand [28] & Bartering between unused recyclables to egg & $15.71 \mathrm{~kg} / \mathrm{member}$ \\
Averaged 10 community-based programs in Thailand [27] & Community recognition and cash return & $18.6 \mathrm{~kg} / \mathrm{member}$ \\
Average 100 school-based programs in Thailand [27] & Community recognition and cash return & $32.13 \mathrm{~kg} / \mathrm{member}$ \\
Thumbon Phang Khon municipality [24] & Community recognition and cash return & $172.20 \mathrm{~kg} / \mathrm{member}$ \\
\hline
\end{tabular}

\subsection{Influences of Socioeconomic, Pro-Environment Attitude and Program Design on Recycling}

Although the relationship between rising incomes and increasing waste generation rate and non-food waste composition is clearly established [3,30,31], participation in recycling activity does not tend to occur spontaneously, and intervention is often required [32]. However, the legal mandate may not be sufficient to influence the public to start recycling as observed in many cities that employed mandatory recycling or high waste management fees. These cities reported adverse incidents such as illegal dumping of waste or low participation in the recycling program. Therefore, creating attractive programs with clear incentives pertaining to participation in the CBM program as well as the right design and an optimal level of incentives are needed in order to boost the chances of the program's success [33,34].

In addition, public outreach programs should also be conducted in order to instill public awareness on ways to preserve the quality of wastes. From the emerging trend of environmental and behavioral adjustment, providing situational feedback on waste quantity and composition at the landfill may also help promote recycling [35] as reported in other behavioral economic studies in developing pro-environment behavior [33].

From Table 3, it can be seen that many studies have identified links between socioeconomic factors and attitudes toward recycling and recycling decisions. The findings, however, are not uniform, varying in accordance with the local context. For example, some socioeconomic factors, such as age and gender, are typically found to correlate with higher levels of recycling practice. Then again, other studies identified a negative relationship between recycling practices and the socioeconomic factors. In contrast, pro-environment behavior such as volunteering for environmental improvement is often reported as a good predictor of pro-recycling behavior. In addition to socio-economic and pro-recycling preferences, the management of the recycling programs also play a critical role in the program design. Small tweaks on the sorting location of recyclables can influence the willingness to join recycling activity [36], the use of advertising to promote recycling [37], frequency of operation and convenience [38], and where the proceeds from recycling activities go [39].

This research was developed to further investigate on the qualitative study of Puangsiri [40]. The study reported that a high percentage of the waste bank members had a strong willingness to participate in the waste bank program and with strong environmental conscientious. This follow up research published by Challcharoenwattana and Pharino [24] was conducted to investigate accounting of MSW flow and greenhouse gas generation from wastes generated in the PKM, as well as the ability of its waste bank program to prevent around $9 \%$ of generated paper, plastic, glass, metals, from entering 
the town's landfill. In addition, the research also found that the performance of the town's waste bank was at $172.20 \mathrm{~kg}$ per member per year that outperformed the average waste bank's operation in Thailand by nine times.

In order to identify socio-economic impacts as well as influencing factors for the group who participated in various recycling modes as well as the non-recycler group. The objectives of this paper was to identify key factors influencing waste bank members' in participation in recycling activities, and provide recommendations for helping other community-based programs to achieve better performance.

Table 3. Selected relationships between socioeconomic, attitudes, and norms toward recycling.

\begin{tabular}{cccc}
\hline \multirow{2}{*}{ Factors } & \multicolumn{3}{c}{ Relationship with Recycling (Only Factors that are } \\
& Statistically Significant) \\
\cline { 2 - 4 } & Positive & Neutral & Negative \\
\hline Increase in age & {$[41]$} & {$[42]$} & {$[43]$} \\
Gender (Male) & & & {$[41,44]$} \\
Levels of education & {$[42,45]$} & & \\
Levels of income & {$[32]$} & {$[42]$} & \\
Number of family members in the household & & & \\
Positive attitude toward recycling & {$[42,45]$} & & \\
Engage in pro-environment activity & {$[42]$} & & \\
\hline
\end{tabular}

\section{Materials and Methods}

\subsection{Description of the Study Site-Phang Khon Municipality (PKM)}

Phang Khon Municipality (PKM), shown on Figure 1, is an area that covers various urban, settlements located in the Sakon Nakorn province in the northeastern region of Thailand. Basic information about PKM is provided in Table 4.

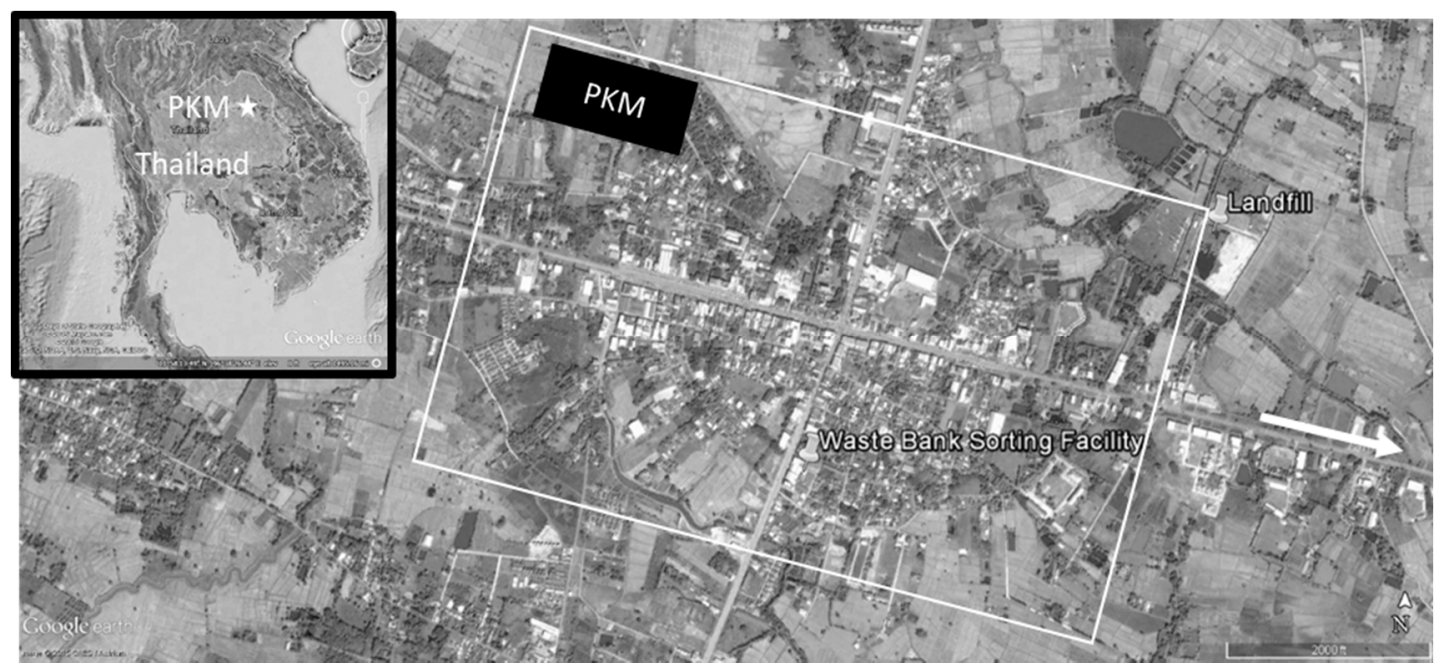

Figure 1. Map of Phang Khon Municipality (scale 1:2000 ft). Source: Google Map [46].

Table 4. Selected statistical figures of Phang Khon Municipality.

\begin{tabular}{cc}
\hline Parameters & Units \\
\hline Registered Population & 16,078 \\
Administrative Area $\left[\mathrm{km}^{2}\right]$ & 54.49 \\
Significant Economic Activities & Agriculture, Mixed Uses \\
Population Density [Persons $\left./ \mathrm{Km}^{2}\right]$ & 295.06 \\
Established MSWM & Yes \\
2008 Gross Provincial Product (GPP) per capita [USD] & 1297 \\
\hline
\end{tabular}


PKM run a traditional MSW disposal at the landfill and curbside recycling through the typical itinerant waste buying system in private business. Nevertheless, PKM also utilized various waste reduction programs to reduce the amount of MSW destined for landfill. Since the waste management fee collected at $0.32 \mathrm{USD} /$ household (exchange rate at $1 \mathrm{USD}=31 \mathrm{THB}$ ) while the cost of waste management in Thailand was around 4.51-9.03 USD/household [47]. Hence, PKM has the direct incentive to divert waste from the landfill as much as possible. Aside from the waste bank project initiated as a part of the waste reduction campaign to facilitate project participation through public-private collaboration, the municipality also promotes biogas generation from household waste and composting [40].

In Figure 2, we can see that the waste bank system has been operated with the help of cooperation among local government officers and volunteers in the community. The waste bank is designed to collect recyclables from its members on a monthly basis, and the members can choose to deposit recyclables at their homes, or they can choose to label their recyclables and deposit them at nearby drop-off locations. The amount of recyclable intake is recorded as per the description framed by the waste bank administrator. The waste bank operators act as traders by purchasing recyclables belonging to the following categories from members: Plastics, paper, glass, aluminum items, and metals. The recyclables are then sorted into more refined categories in order to gain more value. Finally, the municipality sells sorted recyclables to recycling shops. Transactions between the waste bank and its members take place through a credit system. Throughout the following week, members have the opportunity to withdraw their balance. Proceeds from selling recyclables are then saved to be used for supporting a funeral assistance benefit worth approximately 161 USD per member. In 2017, there were approximately 500 members actively participating in the program.

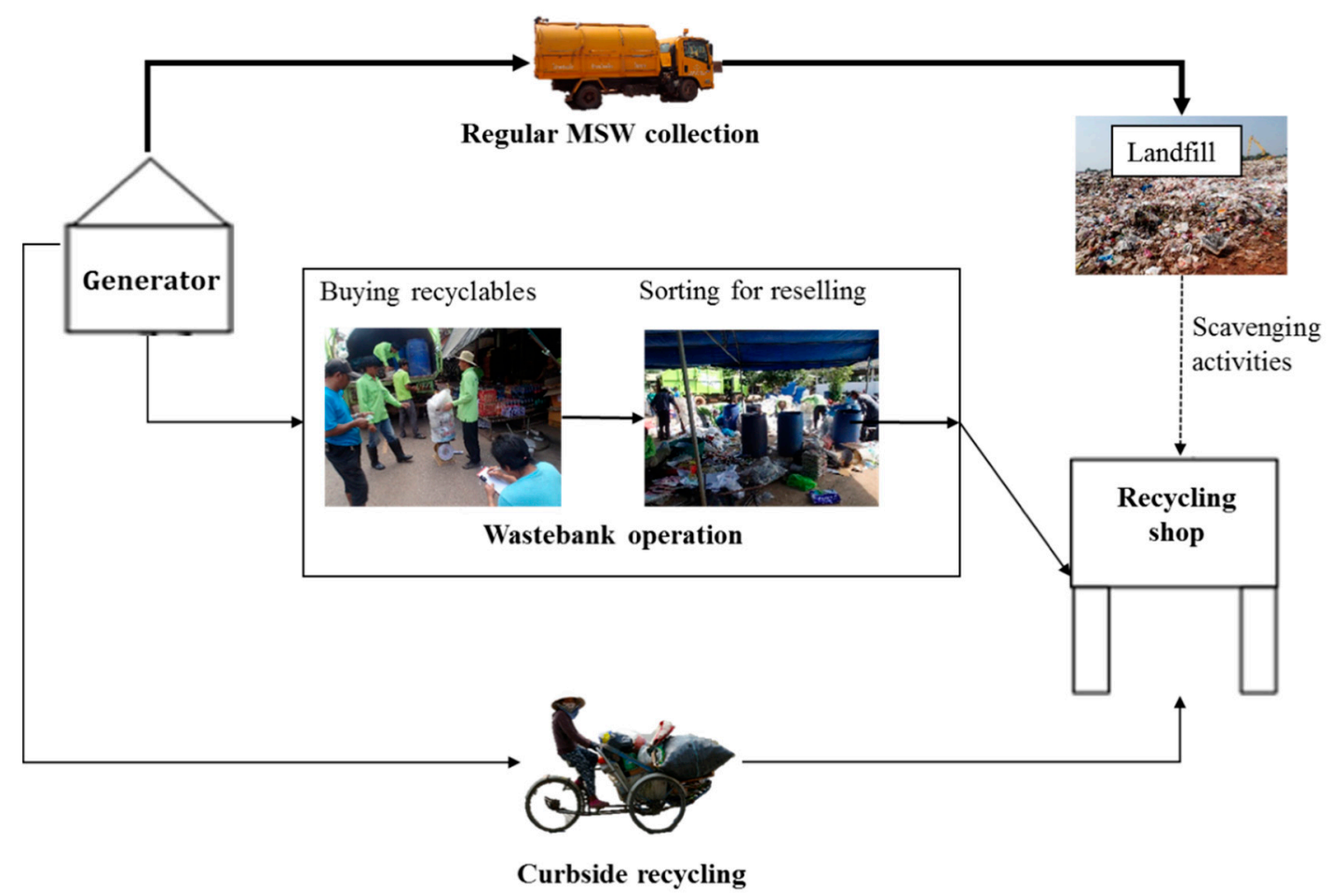

Figure 2. Flow of MSW and recyclables in Phang Khon Municipality (PKM).

\subsection{Questionnaire Development and Deployment}

The questionnaire was designed to capture socioeconomic attribute variables, e.g., age, occupation, and gender, and characteristic variables related to attitudes on waste, recycling, and environmental management. The style and question pattern were developed keeping in mind the format of the 
questionnaires used in two previous studies [48,49]. The details of the questionnaire and explanation are summarized in Table 5.

Table 5. Description of factors used in the analysis.

\begin{tabular}{|c|c|c|}
\hline Category & Code & Description \\
\hline $\begin{array}{l}\text { Dependent } \\
\text { variable }\end{array}$ & mor & $\begin{array}{l}\text { Recycling collection modes among recyclers in Phang Khon Municipality (PKM) } \\
0 \text {-If a respondent states that they do not recycle, or the frequency of recycling is } \\
\text { less frequent than every month } \\
\text { 1-If a respondent recycles through curbside buying at least on a monthly basis } \\
2 \text {-If a respondent is a member of the waste bank and recycles his or her waste at } \\
\text { least on monthly basis } \\
3 \text { - If a respondent recycles at the junk shop at least on a monthly basis }\end{array}$ \\
\hline Socioeconomic & gen & $\begin{array}{l}\text { Gender of a respondent } \\
0 \text { - If a respondent is female } \\
1 \text { - If a respondent is male }\end{array}$ \\
\hline Socioeconomic & $i n c$ & $\begin{array}{l}\text { Income in USD } \\
0 \text { and positive number }\end{array}$ \\
\hline Socioeconomic & $e d u$ & $\begin{array}{l}\text { Highest education level: High school degree (equivalent to 12th grade in the US } \\
\text { education system) } \\
0 \text {-If a respondent has not attained a secondary school degree } \\
1 \text { - If a respondent has attained a secondary school degree or higher }\end{array}$ \\
\hline Socioeconomic & fam & $\begin{array}{l}\text { Number of family members in the household } \\
\text { Positive integer }\end{array}$ \\
\hline Socioeconomic & age & $\begin{array}{l}\text { Age of respondent (year) } \\
\text { Positive integer. The remainder is rounded down }\end{array}$ \\
\hline
\end{tabular}

Perception of MSW crisis: The following statement was posted: Please rank your concern from least concerned, less concerned, concerned, and very concerned with regard to the potential environmental issues of water pollution crisis, air pollution

MSWM attitude cri crisis, global warming crisis, and MSW crisis. Please note that you can only use a rank one time. It cannot be reused

0 - Least or less concerned

1-Concerned or very concerned

The ability to correctly specify good waste management practices (composting, sanitary landfill) and substandard waste management practices (dumping, open

MSWM attitude alt burning, backyard bury)

0 -If a respondent states he or she indulges in substandard practices

1 -If a respondent states he or she indulges in good waste management practices

Whether the average MSW generation rate in the household of respondents exceeds $1.02 \mathrm{~kg} /$ day per capita, a typical MSW generation rate/head published by

MSWM attitude wpc Thailand's Pollution Control Department [1]

0 - Generated MSW is less than $1.02 \mathrm{~kg} /$ day per capita

$1-$ Generated MSW is at or higher than $1.02 \mathrm{~kg} /$ day per capita

Actual

implementation

tre $\begin{aligned} & \text { The ratio of willingness to pay for improving MSW management through recycling } \\ & \text { and the MSWM fee that a respondent has already paid. }\end{aligned}$
MSWM attitude whp $\begin{aligned} & \text { 0-If the respondent is not willing to pay more than the fee that he/she is } \\ & \text { paying now. } \\ & \text { 1-If the respondent is willing to pay more than the fee that he/she is paying now. }\end{aligned}$

Data regarding willingness to pay (WTP) was obtained from selected respondents by asking them about their maximum willingness to pay for improving MSW management through recycling using the payment card method. WTP input in the calculation was estimated by using the midpoint between what respondents stated as their maximum WTP, and the lower WTP level in the payment 
card. Since the study was focused on the respondents' additional WTP of and not the absolute WTP for improving waste management system, WTP findings took the total WTP and divided it by the amount respondents are already paying.

The activities relating to the questionnaire survey were divided across two days. The face-to-face interview method was employed to ensure representativeness of the sample group. The estimated sample size was 400 samples per town with a confidence level of $95 \%$ and expected precision level of $\pm 5 \%$. Fifty additional questionnaires were collected in the event of some questionnaires being disqualified from the sample.

To ensure the quality of the survey, the researchers sent the instructions and description of the questionnaire to a survey coordinator from a local institution. On the day of training, potential surveyors were tested, and discharged if they could not articulate the content of the survey. Some candidate interviewers were let go due to their unreadiness. In the survey, the interviewers were deployed at the household level using stratified random sampling. Each interviewer was assigned the area that he/she was responsible. The interviewer then asked a member of household to answer the questionnaire. The process was repeated until the target of each interviewer was met. The questionnaires was deployed between 25 and 26 October 2013.

\subsection{Analysis of Recycling Preference}

Initially, 450 questionnaires were collected as originally planned. After the survey was completed, inputs from the survey were translated into a format that could be analyzed by SPSS 22 and STATA 13.1. A total of 63 questionnaires were dropped due to reasons such as partially-finished and incoherent answers. The variables used in this study are listed in Table 5.

Standard descriptive statistical analyses, such as average and standard deviations, were employed to explain the results of the survey. For the analysis of preference on tested variables against different types of recycling channels (dependent variable), multinomial logistic regression analysis was employed to test socioeconomic factors, concerns of solid waste crisis, and recycling practice factors. Following the explanation provided in Greene [50], it is assumed that the probability function that respondent to choose recycling collection mode $\mathrm{j}$ is given by

$$
P\left(Y_{i}=j\right)=\left(e^{\beta_{j}^{\prime} X_{i}}\right) /\left(\sum_{k=1}^{4} e^{\beta_{k}^{\prime} X_{i}}\right),
$$

where $\mathrm{j}=0,1,2$, and 3 (collection modes among active recyclers) and $\mathrm{i}=1,2, \ldots, n$ (Sample size).

We normalized the equation by assuming $\beta_{0}=0$; the probability function then becomes

$$
\begin{gathered}
\mathrm{P}\left(\mathrm{Y}_{\mathrm{i}}=\mathrm{j}\right)=\left(\mathrm{e}^{\beta_{\mathrm{j}}^{\prime} \mathrm{X}_{\mathrm{i}}}\right) /\left(1+\sum_{\mathrm{k}=1}^{4} \mathrm{e}^{\beta_{\mathrm{k}}^{\prime} \mathrm{X}_{\mathrm{i}}}\right), \\
\mathrm{P}\left(\mathrm{Y}_{\mathrm{i}}=0\right)=1 /\left(\sum_{\mathrm{k}=1}^{4} \mathrm{e}^{\beta_{\mathrm{k}}^{\prime} \mathrm{X}_{\mathrm{i}}}\right) .
\end{gathered}
$$

Hence, the odds ratio (OR) for respondent $i$ to choose recycling activity $j$ is given by

$$
P_{\mathrm{ij}} / P_{\mathrm{i} 0}=\mathrm{e}^{\beta_{\mathrm{j}} \mathrm{X}_{\mathrm{i}}} .
$$

In this study, we set the option of "if a respondent is a member of the waste bank" as the reference category $(j=0)$. Interpretations of the result can be viewed as how much choice $j$ is preferred by respondent $i$ over the alternative base category $(j=2)$.

\section{Results and Discussion}

\subsection{Descriptive Characteristics}

From Table 6, the descriptive statistical analysis revealed that the average socioeconomic variable respondent in this study is a female with an education level of at least primary school certificate and 
an income of 382 USD per month, as shown in Table 4. The size of family ranged roughly between 3 and 5 members. The sample group consisted mostly of mature adults and the elderly population. To check whether socioeconomic attributes of each recycling group were different, we employed the ANOVA and Bonferroni method as a post hoc test on selected socioeconomic variables, i.e., age and gen variables. The result suggested that the age variable in the study was statistically different ( $p$-value $=0.01, \mathrm{df}=3$ ), and the post-hoc analysis revealed that the difference lay between the non-recycling group and the group that recycles through curbside buying ( mean difference $=4.898, p$-value $=0.014$ ). Nevertheless, the average of the values was still within 40-50 years, which can still be considered as mature adult age. For gen variable, the result from the ANOVA test returned a statistically insignificant result ( $p$-value $=0.511, \mathrm{df}=3$ ). From the above two tests, it can be reasonably assumed that the samples in all groups were relatively homogeneous.

Table 6. Descriptive statistics of variables (mean) in this study.

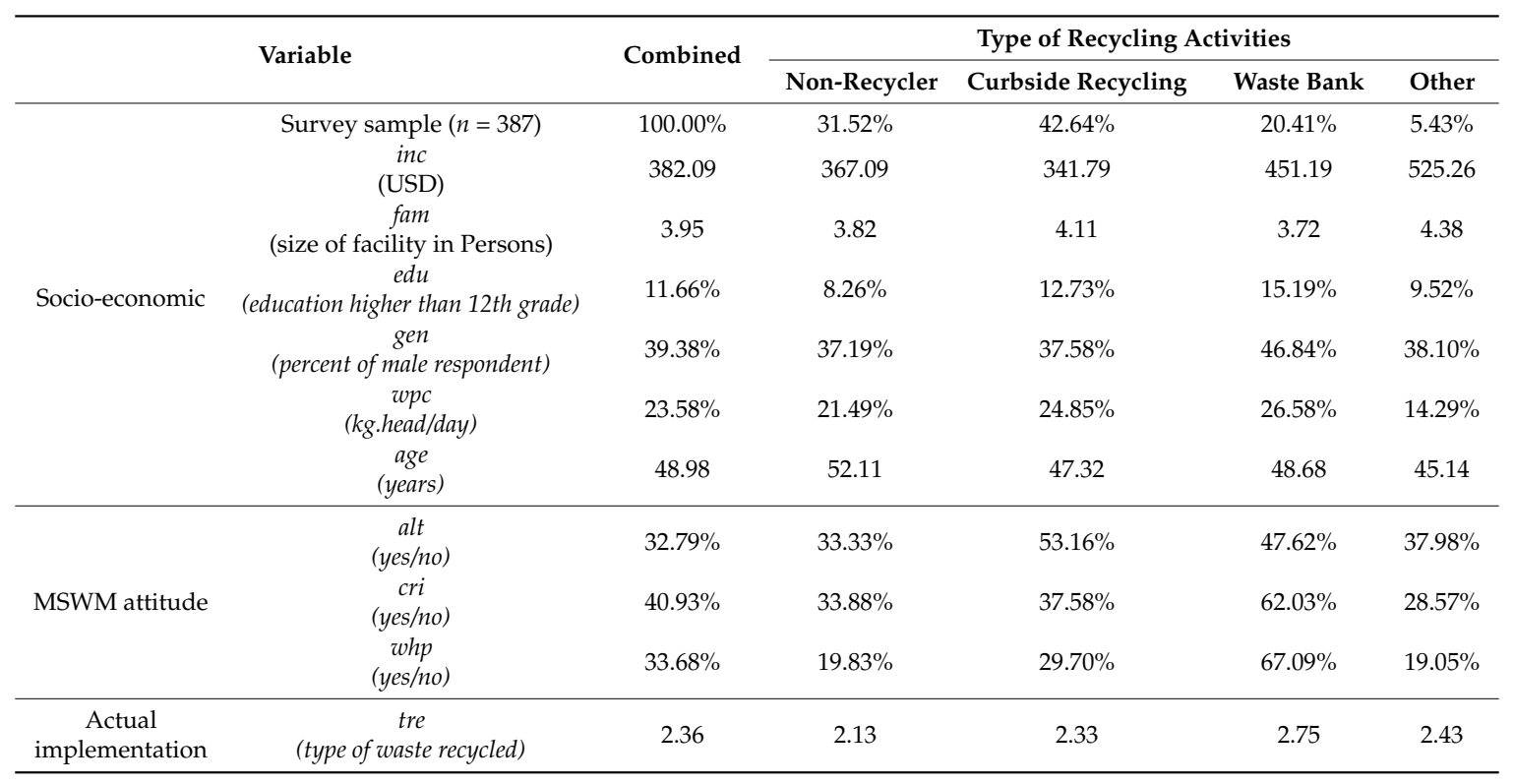

The trend of respondents and population in the province was checked. Since instructions were provided to the interviewers to only survey respondents whose age was between 20 and 80 years, it is appropriate to use the most recent census [51] to compare means between selected variables against populations aged between 20 and 80 years in the same area.

In this research, two variables were selected for testing homogeneity of the population in the area: age and gen. The trend among our respondents and the census are quite similar. For the age variable, the average age from the survey was 49.02 years and the mean population of the province of the age range was 45-92 years. The result from the one sample $t$-test for this variable suggested that the sample from the survey was representative of the population of the province $\left(t_{\text {age }}(386)=0.001, p=0.999\right)$. For the gen variable, the average ratio of males to females from the survey was 0.39 and the mean population of the province was 0.48 . The result from one sample $t$-test suggested that both variables were not different $\left(t_{\mathrm{gen}}(386)=-3.462, p=0.001\right)$. The finding suggested that gender representativeness of the sample group was different from the gender representativeness of the population of the province. Nevertheless, both variables were trending in the same direction with the population.

With regard to environmental management and attitude, the respondents in the waste bank group exhibited a pro-recycling attitude, cri, and separate more recyclables, tre, compared to other groups. In terms of the knowledge in the appropriate waste management system, alt, respondents in the waste bank group provided a proper answer in that composting and recycling are the suitable choices for waste management and stated that MSW solid waste crisis, cri, is the most worrisome issue. Consequently, respondents in the waste bank group formed the highest percentage of people willing 
to pay more for the improvement of waste management system, whp. From the above findings, we can conclude that the recycler in the waste bank group tends to exhibit a more pro-environment and pro-recycling behavior than other groups.

In terms of the popularity of recyclable types among each recycling group, the results in Table 7 revealed that plastic was consistently the most separated compared to other waste types. While the popularity of other recyclables varied from one recycling group to another, the waste bank group consistently recorded the highest participation from all four waste types.

Table 7. Waste separation of the waste type in each group.

\begin{tabular}{ccccc}
\hline \multirow{2}{*}{ Type of Active Recycling Activity } & \multicolumn{4}{c}{$\%$ of Respondents Stating Type of Separated Recyclables } \\
\cline { 2 - 4 } & Plastic & Glass & Paper & Metal \\
\hline Not recycling actively & $70.49 \%$ & $56.56 \%$ & $55.74 \%$ & $31.97 \%$ \\
Curbside buying & $71.52 \%$ & $65.45 \%$ & $59.39 \%$ & $36.97 \%$ \\
Waste bank & $79.75 \%$ & $72.15 \%$ & $69.62 \%$ & $53.16 \%$ \\
Others & $80.95 \%$ & $57.14 \%$ & $80.95 \%$ & $23.81 \%$ \\
\hline
\end{tabular}

For the group that decided against participation in recycling activities, the reasons provided for not engaging in such recycling activities are displayed in Figure 3. The most popular reason was "recycling is complicated/ inconvenient," which led to their unwillingness to participate in recycling. The second reason was that they believed that MSW was not separated completely, usually mixed and landfilled again anyway. This reflects on the need to improve public communication that waste recycling has many benefits for the town and the environment. Other reasons stated in the survey were selected sporadically. The main point is that waste management professionals need to promote waste separation via the education program or knowledge sharing.

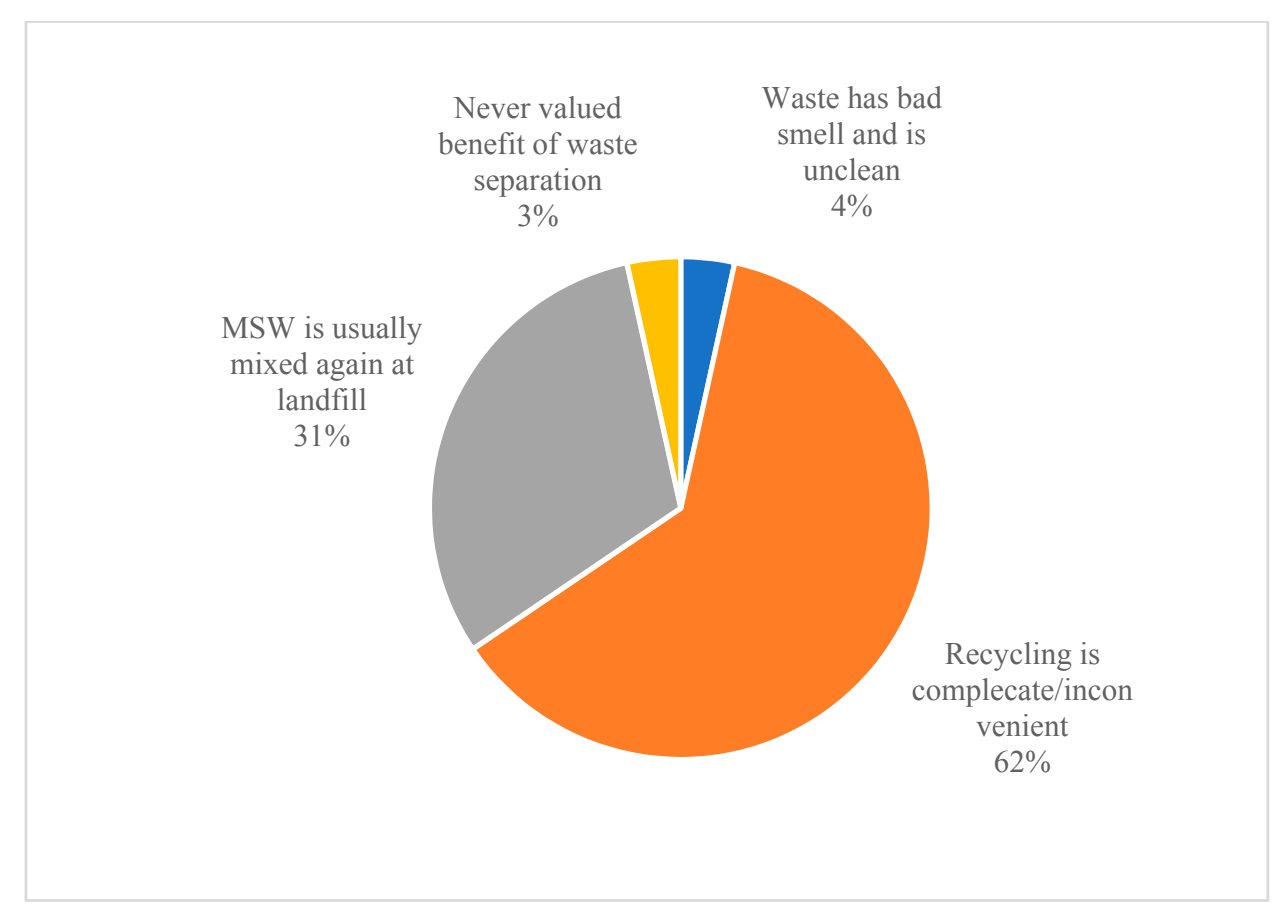

Figure 3. Reasons for not separating waste completely $(n=29)$.

\subsection{Influencing Factors on Recyclers in PKM Areas}

To identify an appropriate model for determining key factors that influence the decision to participate with the waste bank group, McFadden's $\mathrm{R}^{2}$ was selected as the model fitting indicator against the socioeconomic variables only model and the socioeconomic with MSWM variables model. 
Since the McFadden's $\mathrm{R}^{2}$ of the socioeconomic with MSWM variables was greater compared to the McFadden's $R^{2}$ of the socioeconomic variables only model, the odds ratios of the socioeconomic with MSWM variables model were in line with the socioeconomic with MSWM variables.

A socioeconomic variable with statistically significant odds ratios were family size, fam, and, whether the family generated more MSW than a typical family belonging to a similar town, wpc. An in-depth interview with members of the municipality office, who operate the waste bank, revealed that households with a significant amount of recyclables tended not to send their recyclables to the waste bank since the waste bank classified recyclables into fewer categories compared to fully commercialized recycling shops in the area. For example, at the purchasing point of waste bank members, recyclable papers were only separated into four types, namely, thick paper, color paper, office paper, newspaper. In contrast, franchisees of Wongpanit Co.,Ltd., one of the largest recyclable shops in Thailand, distinguished recyclable papers into 13 categories [52]. Nevertheless, the waste bank officer explained that this practice is necessary for the waste bank program since it is limited by manpower constraints.

From Table 8, socioeconomic variables such as income, educational background, age, gender do not influence the decision to participate in one of recycling option statistically. The group of MSWM variables, on the other hand, provided a clear insight into the differentiating factors between the waste bank group and the rest. In terms of additional WTP for waste management, whp, the odds ratios of the waste bank group tended to be more willing to pay to improve the waste management system compared to other groups. The odds ratios on the variables related to attitude toward good practices on waste management, alt and cri, suggested that the waste bank group tended to express more positive attitudes toward composting (a representative of good practice on food waste management) and recycling (a representative of good practice on recyclable waste management) compared to other groups. This attitude transformed into the act of recycling, tre, as the waste bank group tended to separate more waste types compared to other groups.

Table 8. Odds ratios from multinomial logistic regression against socio-economic and MSWM variables.

\begin{tabular}{|c|c|c|c|c|}
\hline \multirow{2}{*}{ Variable } & Non-Active Recycler & Curbside Recycling & Waste Bank & Other Group \\
\hline & Odds Ratio & Odds Ratio & Odds Ratio & Odds Ratio \\
\hline inc & $\begin{array}{c}1.000 \\
(0.000335)\end{array}$ & $\begin{array}{c}1.000 \\
(0.000359)\end{array}$ & & $\begin{array}{c}1.000 \\
(0.000408)\end{array}$ \\
\hline age & $\begin{array}{c}1.016 \\
(0.0136)\end{array}$ & $\begin{array}{c}0.988 \\
(0.0123)\end{array}$ & & $\begin{array}{c}0.980 \\
(0.0208)\end{array}$ \\
\hline fam & $\begin{array}{l}1.104 \\
(0.144)\end{array}$ & $\begin{array}{l}1.283^{* *} \\
(0.155)\end{array}$ & & $\begin{array}{l}1.434 \\
(0.281)\end{array}$ \\
\hline gen & $\begin{array}{c}1.091 \\
(0.390)\end{array}$ & $\begin{array}{l}1.090 \\
(0.357)\end{array}$ & & $\begin{array}{l}1.030 \\
(0.576)\end{array}$ \\
\hline$e d u$ & $\begin{array}{c}0.372 \\
(0.198)\end{array}$ & $\begin{array}{c}0.510 \\
(0.237)\end{array}$ & & $\begin{array}{c}0.283 \\
(0.243)\end{array}$ \\
\hline alt & $\begin{array}{c}0.492 * * \\
(0.173)\end{array}$ & $\begin{array}{l}0.468^{* *} \\
(0.151)\end{array}$ & & $\begin{array}{c}0.737 \\
(0.395)\end{array}$ \\
\hline cri & $\begin{array}{l}0.178^{* * *} \\
(0.0657)\end{array}$ & $\begin{array}{l}0.248^{* * * *} \\
(0.0834)\end{array}$ & & $\begin{array}{c}0.179 * * * \\
(0.107)\end{array}$ \\
\hline$w p c$ & $\begin{array}{c}1.865 \\
(0.831)\end{array}$ & $\begin{array}{l}2.310^{* *} \\
(0.938)\end{array}$ & & $\begin{array}{c}1.565 \\
(1.214)\end{array}$ \\
\hline whp & $\begin{array}{c}0.0609^{* * *} \\
(0.0245)\end{array}$ & $\begin{array}{l}0.122^{* * *} \\
(0.0431)\end{array}$ & & $\begin{array}{c}0.0690^{* * *} \\
(0.0459)\end{array}$ \\
\hline tre & $\begin{array}{l}0.638^{* * *} \\
(0.0756)\end{array}$ & $\begin{array}{l}0.754^{* * *} \\
(0.0817)\end{array}$ & & $\begin{array}{c}0.730 \\
(0.136)\end{array}$ \\
\hline Constant & $\begin{array}{l}13.83^{* *} \\
(14.27)\end{array}$ & $\begin{array}{c}22.66^{* * *} \\
(21.37)\end{array}$ & & $\begin{array}{l}2.646 \\
(3.991)\end{array}$ \\
\hline $\begin{array}{l}\text { Observations } \\
\text { McFadden's R }{ }^{2}\end{array}$ & $\begin{array}{c}386 \\
0.138\end{array}$ & 386 & 386 & 386 \\
\hline
\end{tabular}


Results from this survey compared to other MSW recycling systems reported in Table 3 revealed that since the socioeconomic variables in this study are not statistically significant, except for the family size, the larger family size would less be less like likely to participate in the waste bank and therefore is in contrast to the findings from Ezebilo [44]. In contrast, factors related to the environmental attitude in this study correlate well with another finding presented in Table 3. For example, it is more likely that respondents who are more concerned about the solid waste crisis, cri, separate more types of recyclables, tre, or with a good understanding of appropriate ways for waste management, alt, are in the waste bank group, which is similar to the findings reported in Table 3 where those studies found positive attitude toward recycling and engaging in pro-environment activities. It is therefore imperative for the waste bank advocates to focus on establishing a positive attitude toward recycling and as well as offering hands-on experience with recycling in order to develop a successful waste bank program.

\subsection{Reasons for Joining the Waste Bank}

The authors' previous research collected potential reasons as to why the waste bank members in PKM decided to participate in the program at first. Puangsiri [40] conducted an opinion poll (sample size $=118$ persons) on the waste bank members ( 89 persons). A little more than a quarter $(25.93 \%)$ of respondents joined the waste bank because of their concerns about the well-being of society and $44.99 \%$ joined because the waste bank promotes environmental quality. While direct financial return, i.e., cash from selling recyclables, was responsible for the remaining percentage $(22.51 \%)$ of the overall decision for joining the waste bank. This was significantly different from the other group of respondents (non-waste bank members (29 persons)) because $37.93 \%$ of the non-members stated that they might join the waste bank if the financial incentive was sufficiently attractive. Interestingly, respondents from this group stated that they might join the waste bank if they felt that it made them a part of the community.

With regard to the factors that help in sustaining participation with the waste bank, the overall combined result indicated that convenience, community peer pressure, and the sufficient volume of recyclables collection play a critical role in continuing participation. To draw parallel on the power of community and press pressure, examples of the reasoning for members of The Young Men's Christian Association (YMCA) for joining and sustaining memberships were different [53]. While top given reasons for joining YMCA were that the members were looking for place for exercise and a variety of equipment, those members stated the reason of having a sense of belonging in the group with shared interest. The same book also stated that the peer pressure could also be used as a leverage for pressuring members of a community to consider joining the effort of pushing for social change.

It is worth noting that Mongkolnchaiarunya [28] reported that other recycling-related CBM participation in the program peaked during the first few months, as households sent their recyclables to the CBM. However, the participation rate dropped to almost no participation as recyclables were generated in small quantities. In the non-member group, $82.76 \%$ of respondents overwhelmingly stated that waste collection must be simplified, so that it is easy to sort.

\section{Recommendations and Implementation Plan}

In 2016, Thailand created the National Master Plan for Waste Management for 2016-2020 [54]. The use of the waste bank to mitigate the MSW crisis has been incorporated in the national master plan. However, it was only aimed at being deployed in academic institutions, but not in other places. The waste bank can be effective in community-setting if the program is managed effectively as demonstrated in this paper. Therefore, lessons learned from the waste bank can help in formulating recommendations for expanding recycling practices to other towns.

The same success can be achieved at a broader level through consistent and efficient policies. The following section presents two critical aspects that should be implemented in national and local policies in order to promote participation in waste reutilization programs. 


\subsection{Implementation of Waste Bank Program}

As demonstrated by the case study, PKM's waste bank implemented the combination of public awareness rising through ongoing education and peers; offering convenience for recycling through curbside and drop-off pickup of recyclables; and using a commitment device such as funeral assistance program as the tools for the sustainable recycling program. Hence, other towns that intend to develop the waste bank program should ensure that the quality above is included into the program implementation.

In term of the implementation timeline for the waste bank, PKM used the fact that the old landfill was reaching its maximum capacity. Moreover, the waste reduction must be implemented in order to conserve the new landfill capacity. The municipality then implemented the waste minimization program that the waste bank is also one of the measures for waste minimization. Sustaining participation of the waste bank was done through peer influencers such as community leaders and representative of the villages.

\subsection{Additional Financial Revenue}

A financial incentive is a powerful tool for promoting reutilization activity if it demonstrates benefits to both recyclers and waste management authorities. In this study, waste bank members tended to express additional willingness to pay for improving recycling. Therefore, it may be possible to use it in reverse as an extra source of income generation. The lesson learned from this project demonstrated that once a recycler becomes more experienced, they may also opt to sell the waste themselves in order to obtain a better financial return. From Puangsiri [40], perks in this particular program, such as a funeral assistance fund for the waste bank members, can be used to incentivize members to join or continue their participation with the waste bank. In the long run, an impact from urbanization where waste generation rate per capita is likely to rise, and waste generator may opt to recycle through other means or skip recycling completely, transferring the waste bank project into public-private partnership or privatization may be required. This application will help to free some shortcoming of the publicly-run waste bank as manpower can be adjusted more flexibly, resulting in more frequent recyclable pick up and more sensitively purchased waste type.

\subsection{Linking the Waste Bank with Mitigating Climate Change}

Waste management has been designated as one of the national determined contribution measures for reducing greenhouse gas(GHG) emission by 2030 under Thailand's Nationally Determined Contribution Roadmap on Mitigation 2021-2030 [55]. It is a possibility that waste minimization activities such as waste bank programs can also generate avoided GHG emission, and therefore be able to obtain a new revenue steam under Thailand's carbon credit scheme "Thailand Voluntary Emission Reduction Program" (T-VER) by Thailand Greenhouse Gas Management Organization (Public Organization): TGO.

Although the protocols for recognizing avoided GHG emissions are still being developed under the T-VER program, similar protocols under the Clean Development Mechanism (CDM) for recognizing avoided GHG emission by waste recycling are available: AMS-III.BA: Recovery and recycling of materials from E-waste-Version 1.0 [56] and AMS-III.AJ.: Recovery and recycling of materials from solid wastes-Version 6.0 [57]. However, there is only one material recycling activity that is listed on UNFCCC: Project 9739: Greenhouse gas emissions' reduction by recovering metals and materials through electronic waste collection and recycling process is performed at the Attero Recycling Pvt Ltd. plant which is located in Roorkee, Uttarakhand, India [58].

Once such T-VER methodology for waste recycling is established, several market forces are available to support the cause that may incentivize recyclers to participate. As surveyed by TGO, several firms in Thailand have purchased T-VER credits to offset their carbon footprints which rise as a result of business operations at the rate between 0.97 and 9.68 USD per ton CO2-eq. Moreover, 
these firms have often specified that T-VER credits have to be derived from projects that also create additional co-benefits, e.g., landfill gas incineration and reforestation. Given that some recyclers are sensitive about the value of recyclables, added incomes should provide significant incentives for them to increase their wiliness to recycle.

\section{Conclusions}

The members of PKM and the non-members of the waste bank provide significant insights into differentiating characteristics. The results from this study revealed that attitudes of recyclers who are members of the waste bank, non-waste bank members, and non-active recyclers in PKM were distinguishable. While basic socio-economic factors, such as age, income, and gender were not able to provide insight into the likelihood to participate in different recycling activities. Pro-recycling attitudes such as the concern on the solid waste crisis; the mentioning of recycling/composting/sanitary landfilling as an appropriate way to manage MSW; and lower additional willingness to pay for improvement of MSWM are good predictors of participation in the waste bank group compared to MSW recycling in other modes. The weak points of the waste bank were also identified. Although, economics of scale, in terms of the quantity of recyclables, as well as the size of family, suggested that recyclers that generate more waste tended to prefer to sell directly to recyclable buyers.

In term of policy recommendation, PKM's waste bank achieved a remarkable milestone in rallying support from its members through awareness rising; peer pressure and ease-of-access to recycle collection services. Additionally, ways to provide incentives to the members of the waste bank includes adding commitment devices, e.g., perks of belonging to the recycling program, or recognition. In addition, theoretical possibility of linking the ability to avoid GHG emission through recycling and potential climate finance may be able to provide additional convincing factors to the participation of the recycling program.

\section{Research Highlights:}

- Members of community-based recycling programs have a greater understanding of its impact in waste management than non-member groups.

- Socioeconomic factors do not tend to be strong predictors in comparison to environmental awareness factors.

- Introducing a sense of community and peer pressure is identified as a key driver for higher recycling rates.

Author Contributions: Authors equally contributed to the research question framework development and methodology designed; collection and analyzed the data; wrote the manuscript and edited the manuscript.

Acknowledgments: This research was supported by Rachadapisek Sompote Fund for Postdoctoral Fellowship, Chulalongkorn University.

Conflicts of Interest: The authors declare no conflict of interest.

\section{Abbreviations}

$\begin{array}{ll}\text { CBM } & \text { Community-Based Management } \\ \text { GHG } & \text { Greenhouse Gas } \\ \text { PKM } & \text { Phang Khon Municipality } \\ \text { MSW } & \text { Municipal Solid Waste } \\ \text { MSWM } & \text { Municipal Solid Waste Management } \\ \text { PCD } & \text { Thailand's Pollution Control Department } \\ \text { WTP } & \text { Willingness to Pay }\end{array}$

\section{References}

1. PCD. Thailand State of Pollution Report B.E. 2555 (2012); Thailand's Pollution Control Department: Bangkok, Thailand, 2013.

2. The World Bank. What a Waste: Solid Waste Management in Asia; The World Bank: Washington, DC, USA, 1999; Available online: http:/ / documents.worldbank.org/curated/en/694561468770664233/What-a-wastesolid-waste-management-in-Asia (accessed on 25 November 2018). 
3. Hoornweg, D.; Bhada-Tata, P. What a Waste: A Global Review of Solid Waste Management; The Worldbank: Washington, DC, USA, 2012.

4. PCD. Thailand State of Pollution Report B.E. 2559 (2016); Thailand's Pollution Control Department: Bangkok, Thailand, 2017.

5. PCD. Survey and Analysis of Municipal Solid Waste Characteristics of all Municiplaities in Thailand; Thailand's Pollution Control Department: Bangkok, Thailand, 2004.

6. Department of Local Administration. MSW Management Plan in Local Government; Department of Local Administration: Bangkok, Thailand, 2015.

7. Challcharoenwattana, A. Improving Municipal Solid Waste Management through Recycling in Urban Settlements of Thailand; Chulalongkorn University: Bangkok, Thailand, 2015.

8. Renkow, M.; Keeler, A.G. Determining the Optimal Landfill Size: Is Bigger Always Better? J. Environ. Manag. 1996, 46, 67-75. [CrossRef]

9. Sasao, T. An estimation of the social costs of landfill siting using a choice experiment. Waste Manag. 2004, 24, 753-762. [CrossRef] [PubMed]

10. Nahman, A. Pricing landfill externalities: Emissions and disamenity costs in Cape Town, South Africa. Waste Manag. 2011, 31, 2046-2056. [CrossRef] [PubMed]

11. Seok Lim, J.; Missios, P. Does size really matter? Landfill scale impacts on property values. Appl. Econ. Lett. 2007, 14, 719-723. [CrossRef]

12. ThaiPublica. National Agenda on National Solid Waste Management Plan. Available online: http:// thaipublica.org/2014/08/praksa-1/ (accessed on 31 Janurary 2015).

13. Thailand's Pollution Control Department (PCD). Thailand State of Pollution Report B.E. 2558 (2015); Thailand's Pollution Control Department: Bangkok, Thailand, 2016.

14. Laner, D.; Fellner, J.; Brunner, P.H. Flooding of municipal solid waste landfills-an environmental hazard? Sci. Total Environ. 2009, 407, 3674-3680. [CrossRef] [PubMed]

15. Nadal, M.; Rovira, J.; Diaz-Ferrero, J.; Schuhmacher, M.; Domingo, J.L. Human exposure to environmental pollutants after a tire landfill fire in Spain: Health risks. Environ. Int. 2016, 97, 37-44. [CrossRef] [PubMed]

16. Aderemi, O.A.; Falade, C.T. Environmental and Health Concerns Associated with the Open Dumping of Municipal Solid Waste: A Lagos, Nigeria Experience. Am. J. Environ. Eng. 2012, 2, 160-165. [CrossRef]

17. Ahel, M.; Mikac, N.; Cosovic, B.; Prohic, E.; Soukup, V. The impact of contamination from a municipal solid waste landfill (zagreb, croatia) on underlying soil. Water Sci. Technol. 1998, 37, 203-210. [CrossRef]

18. Ahmed, A.M.; Sulaiman, W.N. Evaluation of Groundwater and Soil Pollution in a Landfill Area Using Electrical Resistivity Imaging Survey. Environ. Manag. 2001, 28, 655-663. [CrossRef]

19. Wangyao, K.; Towprayoon, S.; Chiemchaisri, C.; Gheewala, S.H.; Nopharatana, A. Application of the IPCC Waste Model to solid waste disposal sites in tropical countries: Case study of Thailand. Environ. Monit. Assess. 2010, 164, 249-261. [CrossRef] [PubMed]

20. Gunsilius, E.; Chaturvedi, B.; Scheinberg, A. The Economics of the Informal Sector in Solid Waste Management; GIZ_Deutsche Gesellschaft für Internationale Zusammenarbeit (GIZ) GmbH: Bonn, Germany, 2011.

21. Kinnaman, T.C.; Fullerton, D. Garbage and Recycling with Endogenous Local Policy. J. Urban Econ. 2000, 48, 419-442. [CrossRef]

22. Ojeda-Benitez, S.; Armijo-de-Vega, C.; Ramírez-Barreto, M.E. Formal and informal recovery of recyclables in Mexicali, Mexico: Handling alternatives. Resour. Conserv. Recycl. 2002, 34, 273-288. [CrossRef]

23. Wilson, D.; Whiteman, A.; Tormin, A. Strategic Planning Guide for Municipal Solid Waste Management; The World Bank: Washington, DC, USA, 2001.

24. Challcharoenwattana, A.; Pharino, C. Co-Benefits of Household Waste Recycling for Local Community's Sustainable Waste Management in Thailand. Sustainability 2015, 7, 7417-7437. [CrossRef]

25. Zero Waste Houston Coalition. It's Smarter to Separate; Texas Campaign for the Environment Fund: Houson, TX, USA, 2014; Available online: https: / / www.texasenvironment.org/wpcontent/uploads/2015/ 04/ItsSmartertoSeparate_TCEZeroWasteHoustonReport_July2014.pdf (accessed on 25 November 2018).

26. Kurniawan, T.A.; Puppim de Oliveira, J.; Premakumara, D.G.J.; Nagaishi, M. City-to-city level cooperation for generating urban co-benefits: The case of technological cooperation in the waste sector between Surabaya (Indonesia) and Kitakyushu (Japan). J. Clean. Prod. 2013, 58, 43-50. [CrossRef]

27. Suttibak, S.; Nitivattananon, V. Assessment of factors influencing the performance of solid waste recycling programs. Resour. Conserv. Recycl. 2008, 53, 45-56. [CrossRef] 
28. Mongkolnchaiarunya, J. Promoting a community-based solid-waste management initiative in local government: Yala municipality, Thailand. Habitat Int. 2005, 29, 27-40. [CrossRef]

29. Municipality, R.C. 2012 Report of Waste Bank Operation; Rayong City Municipality: Rayong, Thailand, 2013; p. 8.

30. Memon, M.A. Integrated solid waste management based on the 3R approach. J. Mater. Cycles Waste Manag. 2010, 12, 30-40. [CrossRef]

31. UNEP. Global Waste Management Outlook; UNEP: Nairobi, Kenya, 2015.

32. Lee, S.; Paik, H.S. Korean household waste management and recycling behavior. Build. Environ. 2011, 46, 1159-1166. [CrossRef]

33. The Cabinet Office Behavioural Insights Team. Test, Learn, Adapt: Developing Public Policy with Randomised Controlled Trials; Cabinet Office: London, UK, 2012.

34. Ölander, F.; Thøgersen, J. Informing Versus Nudging in Environmental Policy. J. Consum. Policy 2014, 37 , 341-356. [CrossRef]

35. The Cabinet Office Behavioural Insights Team. Applying Behavioural Insights to Reduce Fraud, Error and Debt; Cabinet Office: London, UK, 2012; p. 38.

36. Czajkowski, M.; Hanley, N.; Nyborg, K. Social Norms, Morals and Self-interest as Determinants of Pro-environment Behaviours: The Case of Household Recycling. Environ. Resour. Econ. 2015, 66, 647-670. [CrossRef]

37. Chan, K. Mass communication and pro-environmental behaviour: Waste recycling in Hong Kong. J. Environ. Manag. 1998, 52, 317-325. [CrossRef]

38. Tonglet, M.; Phillips, P.S.; Bates, M.P. Determining the drivers for householder pro-environmental behaviour: Waste minimisation compared to recycling. Resources, Conserv. Recycl. 2004, 42, 27-48. [CrossRef]

39. Granzin, K.L.; Olsen, J.E. Characterizing Participants in Activities Protecting the Environment: A Focus on Donating, Recycling, and Conservation Behaviors. J. Public Policy Mark. 1991, 10, 1-27.

40. Puangsiri, S. Carbon Accounting System from Integrated Municipal Waste Management in Thailand: Case Study Sakhonnakhon Province; Chulalongkorn University: Bangkok, Thailand, 2010.

41. Afroz, R.; Hanaki, K.; Tuddin, R.; Ayupp, K. A survey of recycling behaviour in households in Dhaka, Bangladesh. Waste Manag. Res. J. Int. Solid Wastes Public Clean. Assoc. ISWA 2010, 28, 552-560. [CrossRef] [PubMed]

42. Czajkowski, M.; Kądziela, T.; Hanley, N. We want to sort! Assessing households' preferences for sorting waste. Resour. Energy Econ. 2014, 36, 290-306. [CrossRef]

43. Song, Q.; Wang, Z.; Li, J. Residents' behaviors, attitudes, and willingness to pay for recycling e-waste in Macau. J. Environ. Manag. 2012, 106, 8-16. [CrossRef] [PubMed]

44. Ezebilo, E.E. Willingness to pay for improved residential waste management in a developing country. Int. J. Environ. Sci. Technol. 2013, 10, 413-422. [CrossRef]

45. Zen, I.S.; Noor, Z.Z.; Yusuf, R.O. The profiles of household solid waste recyclers and non-recyclers in Kuala Lumpur, Malaysia. Habitat Int. 2014, 42, 83-89. [CrossRef]

46. Google. Google Map; Google: Mountain View, CA, USA, 2015.

47. Panswad, D.; Panswad, T. Misunderstanding and Observation on New MSW Management Fee. Bangkok Biz News, 2016.

48. Afroz, R.; Hanaki, K.; Hasegawa-Kurisu, K. Willingness to pay for waste management improvement in Dhaka city, Bangladesh. J. Environ. Manag. 2009, 90, 492-503. [CrossRef] [PubMed]

49. Arayameth, A. Household Behavior and Willingness to Pay for Waste Separation; Thammasat University: Krung Thep Maha Nakhon, Thailand, 2003.

50. Greene, W.H. Econometric Analysis; Pearson Education: London, UK, 2003.

51. National Statistical Office. Summary of Household Economic and Social Conditions of 2013 (B.E. 2556); National Statistical Office: Bangkok, Thailand, 2014.

52. Wongpanit. Price Schedule; Wongpanit: Bangkok, Thailand, 2013.

53. Duhigg, C. The Power of Habit: Why We Do What We Do in Life and Business; Random House: New York, NY, USA, 2012.

54. PCD. National Master Plan for Waste Management (2016-2020); Active Print Co., Ltd.: Bangkok, Thailand, 2016. 
55. Saiyasitpanich, P. Nationally Determined Contribution Roadmap on Mitigation 2021-2030; Office of Natural Resources and Environmental Policy and Planning, Ministry of Natural Resources and the Environment: Bangkok, Thailand, 2017.

56. CDM-Executive Board. III.BA. Recovery and Recycling of Materials from E-Waste; UNFCCC: Bonn, Germany, 2012.

57. CDM-Executive Board. Recovery and Recycling of Materials from Solid Wastes; UNFCCC: Bonn, Germany, 2017.

58. Attero Recycling Private Limited. Project 9739: Greenhouse Gas Emissions Reduction by Recovering Metals and Materials through Electronic Waste Collection and Recycling Process Performed at Attero Recycling Pvt Ltd. Plant Located in Roorkee, Uttarakhand, India; Attero Recycling Private Limited: Noida, India, 2013.

(C) 2018 by the authors. Licensee MDPI, Basel, Switzerland. This article is an open access article distributed under the terms and conditions of the Creative Commons Attribution (CC BY) license (http:// creativecommons.org/licenses/by/4.0/). 